\author{
Artur Maroń \\ ORCID: 0000-0002-7657-7602 \\ Uniwersytet Wrocławski
}

\title{
Wokół pojęcia pogromu w refleksji nad przemocą antyromską
}

Abstrakt: Artykuł przedstawia dotychczasowe wyniki badań autora nad pojęciem pogromu i ustalenia związane z przemocą antyromską w Oświęcimiu w 1981 roku. Rozważania koncentrują się na krytyce istniejących hipotez i teorii wyjaśniających ówczesne wydarzenia oraz uzasadniają tezę o ich pogromowym charakterze. Główna teza artykułu oparta jest na odwołaniu się do teoretycznych ustaleń z raportu Anny Gizy-Poleszczuk i Jana Poleszczuka na temat przemocy w Mławie (1991) oraz zastosowanej przez nich teorii stereotypu Stanisława Ossowskiego, odwołaniu do artykułu Piotra Foreckiego o kategorii pogromu w badaniach nad antysemickim wymiarem marca ' 68 i definicji pogromu Lecha Nijakowskiego.

Słowa-klucze: pogrom, Romowie, Oświęcim, dyskryminacja, zbiorowa przemoc, nacjonalizm

Refleksja nad przemocą antyromską w Oświęcimiu w 1981 roku wywołała pytania o charakter tych i podobnych wystąpień w PRL. Zarówno w odniesieniu do zamieszek antyromskich w Łukowie i Kłodawie w 1976 roku, jak i w Koninie i Oświęcimiu w 1981 roku sami Romowie mówią i piszą o „pogromach”. Pojęcie to jest mocno w Polsce kojarzone z okresem II wojny światowej i niesie z sobą wiele niejasności.

Najczęściej pogromy antyromskie nie są zjawiskami masowymi, jeśli chodzi o liczebność osób biorących w nich udział zarówno ze strony sprawców, jak i ofiar, ale podobnymi do pogromów antyżydowskich, jeśli chodzi o ich charakter społeczny. Dlatego bardzo często w stosunku do pogromów antyromskich i do wszystkich wydarzeń do nich podobnych można się spotkać z zastrzeżeniem, że nie były to w istocie pogromy, gdyż te miały mieć miejsce w czasie wojny i po-

* Tekst stanowi część badań prowadzonych w ramach doktoratu nad przemocą antyromską w PRL w kontekście ciągłości polskiego nacjonalizmu.

${ }^{1}$ S. Kapralski, Refleksje o pogromach. Na marginesie wydarzeń w Oświęcimiu w 1981 r., „Studia Romologica” 2009, nr 2, s. 242-243. Zob. także R. Kwiatkowski, Przystanek Oświęcim (rozm. przepr. Karolina Feć), http://nowaorgiamysli.pl/index.php/2017/06/10/roman-kwiatkowski-przystanek-oswiecim-romska-historia/ (dostęp: 8.04.2020). 
chłonęły setki ofiar ${ }^{2}$, a lokalne konflikty, w których bierze udział kilkaset osób i nikt nie ginie, to „zatargi” lub tylko „zamieszki”. Do zbiorowej przemocy antyromskiej niechętnie dodaje się przymiotnik „,pogromowa”; istnieje również trudność w prostym przełożeniu doświadczeń żydowskich w tym względzie. Panujące przekonanie, że istnieje paradygmatyczny przykład pogromu, najpewniej antyżydowskiego, jest równie złudne i zwodnicze co przekonanie, że w historii mieliśmy do czynienia z paradygmatycznymi rewolucjami ${ }^{3}$, w szczególności rewolucją francuską, która odtąd stanowi wzorzec, do którego należy przykładać inne zdarzenia tego typu ${ }^{4}$. Drugi zasadniczy błąd w definiowaniu zjawiska pogromu, według Daniela Grinberga, to uciekanie się do gęstego opisu konkretnych zdarzeń przemocy zbiorowej. Bez odróżnienia, co jest istotne, i przeciwstawienia tego temu, co jest drugorzędne, nie da się zrozumieć ani tym bardziej wyjaśnić mechanizmu pogromu i jego charakteru. Znacząca jest uwaga Sławomira Kapralskiego, ,że pojęcie »pogromu« dzieli los wszystkich tych, które denotują zjawisko powszechnie znane i rozpoznawalne, nie posiadając przy tym precyzyjnej definicji”" Niechęć w definiowaniu zjawisk pogromowych wynika z bardzo silnego zwyczajowego jego rozumienia i zakorzenienia w pamięci zbiorowej. Podobnie sprawę widzi Lech Nijakowski, który stwierdza, że

często w pracach socjologów brakuje definicji tych pojęć. Ponadto socjologię cechuje niechęć do rewizji istniejącej siatki pojęciowej, emocjonalny, moralistyczny i upolityczniony charakter dyskursu na temat zbiorowej przemocy oraz niedostrzeganie pewnych poziomów agregacji aktów przemocy ${ }^{6}$.

Problem jest zarówno terminologiczny, a więc teoretyczny, jak i polityczno-ideologiczny. Za niejasność w odniesieniu do tego, co można uznać za pogrom, odpowiadają także obciążenie historyczne i tradycyjny, zwyczajowy, ukształtowany w dużej mierze przez traumy II wojny światowej, zwrot ku pogromowi jako masakrze. Można powiedzieć, że termin „pogrom” wywołuje trudności — ma on znaczenie tradycyjne, nieformalne - tożsame z masakrą i masowym mordem, a formalnie jest rozmyte lub niejasne. Do takiego wniosku doszedł Lech Nija-

2 Rozumienie pogromu autorstwa Lecha Nijakowskiego, które omawiam w dalszej części pracy, akcentuje ten ilościowy aspekt i podnosi go do rangi kryterium odróżniającego pogromy od innych zjawisk. Owo kryterium, narzucające się i jednocześnie dość przypadkowe, ewokuje wiele problemów, nasuwa wątpliwości, lecz także stanowi punkt wyjścia dyskusji o definicji pogromu.

${ }^{3}$ D. Grinberg, Wokót idei pogromów. Definicje, główne szkoły interpretacji, źródła nieporozumień, [w:] Pogromy Żydów na ziemiach polskich w XIX i XX wieku, t. 3. Historiografia, polityka, recepcja społeczna (do 1939 roku), red. K. Kijek, A. Markowski, K. Zieliński, Warszawa 2019, s. 16.

${ }^{4}$ Ibidem.

${ }^{5}$ S. Kapralski, op. cit., s. 242.

${ }^{6}$ L. Nijakowski, Rozkosz zemsty. Socjologia historyczna mobilizacji ludobójczej, Warszawa 2013, s. 61. 
kowski, który wini środowisko naukowe za tę sytuację jawnej niechęci, jeśli nie wrogości wobec definiowania i redefiniowania tego i innych terminów? ${ }^{7}$.

Słowniki nie podają jednoznacznie, czy pogrom musi być masakrą. W ujęciu historycznym oba te pojęcia były tożsame, ale zdarzenia z lat trzydziestych XX wieku, w szczególności pogromy antyżydowskie bez ofiar śmiertelnych, postawiły pod znakiem zapytania kwestię tego, czym jest pogrom i co można powiedzieć o przemocy, której skutkiem i celem nie jest zabijanie, ale brutalny atak na mniejszość w warunkach kryzysu gospodarczego lub wojny.

W toku badań nad sytuacją Romów w 1981 roku w Oświęcimiu i Koninie oraz analizy terminu ,pogrom” brakuje wyraźnej i jasnej definicji tego, co można za pogrom uznać; okazuje się on również splątany z czynnikami politycznymi i polskim nacjonalizmem, który według niektórych ujęć jest obecny w polskiej nauce i odpowiada za eufemizację, a czasem wręcz wyrugowanie tego terminu, obarczonego ciężarem winy ${ }^{8}$.

Ustalenie znaczenia terminu ,pogrom" i utworzenie z niego pojęcia teoretycznego jest jednym z postulatów badawczych prowadzonych przeze mnie badań W niniejszym tekście zasadnicze ustalenia można ująć w czterech punktach-postulatach:

1. sproblematyzowanie eufemizacji pogromu jako jednej z podstawowych przeszkód w badaniach nad przemocą wobec mniejszości romskiej;

2. zastosowanie definicji pogromu Lecha M. Nijakowskiego, prowadzące do uwolnienia się od fałszywych sporów. Uznanie go za konieczny, lecz niewystarczający punkt wyjścia;

3. przesunięcie akcentu na odróżnienie pogromów od zamieszek (nie - linczów i masakr);

4. krytyczne zastosowanie założeń Anny Gizy-Poleszczuk i Jana Poleszczuka, które pozwala dostrzec analogie w wydarzeniach w Mławie (1991) i Oświęcimiu (1981).

Dodajmy, że za eufemizacją, wymienioną w punkcie pierwszym, idą dalsze konsekwencje, a więc niechęć do podejmowania refleksji i mówienia o zjawiskach przemocy, w których Polacy byli po stronie sprawców, a nie ofiar. Do podobnych wniosków doszedł Piotr Forecki, który pisał o eufemizacji zdarzeń o charakterze pogromowym, a także o zadziwiających praktykach towarzyszących badaniom antysemityzmu i wypędzaniu Żydów z Polski ${ }^{9}$. Zjawisko eufemizacji korzysta z niejednoznaczności pogłębionej przez historię pogromu w języku polskim. Jego

7 Ibidem.

${ }^{8} \mathrm{O}$ usuwaniu z pola widzenia polskiej winy za pogromy zob. P. Forecki, Marzec '68 jako pogrom. Brakujaca kategoria opisu, [w:] Tożsamość po pogromie. Zapisy literackie pokolenia marca '68, red. P. Czapliński, A. Molisak, Warszawa 2019, s. 23-24; oraz w tym kontekście o pojęciu eksterioryzacji por. L. Nijakowski, op. cit., s. 37.

${ }^{9}$ P. Forecki, op. cit., s. 21-24. 
definicja jest kwestią otwartą i dyskusyjną oraz pozostawia pole do interpretacji, co utrwala problem już na gruncie samego języka.

W słowniku polszczyzny XVI wieku czytamy, że „pogrom” to synonim klęski i porażki, przegranej bitwy, spustoszenia i doświadczenia szkód. Od pogromu można „uciekać, ubieżać”, ale można też pogrom „uczynić”. Sytuacja zmienia się w XVII wieku, od kiedy to „pogrom” staje się całkowitym zniszczeniem wojsk nieprzyjacielskich i synonimem zwycięstwa, a także rzezią innowierców ${ }^{10}$. „Pogromić” było rutenizmem i oznaczało pierwotnie 'skrzyczeć, złajać, ofuknąć', a w znaczeniu bardziej współczesnym „pogromić” to 'zwyciężyć, pokonać w boju'; zostało przejęte z języka ukraińskiego lub rosyjskiego. Tak więc już od czasów staropolskich pogrom wywoływał skojarzenie z masakrą lub totalną klęską, ewentualnie rzezią innowierców. Jednak we współczesnym Polskim słowniku judaistycznym w haśle „pogrom” autor, Rafał Żebrowski, dystansuje się od jednoznacznej definicji:

Określenie odnoszące się między innymi do gwałtownych wystąpień jednej grupy ludności przeciw drugiej, przede wszystkim wiążące się z prześladowaniem mniejszości narodowych i religijnych, w których zakres wchodzą zabójstwa, gwałty, przypadki pobić i zranień, niszczenia dobytku i rabunku (nie muszą one występować wszystkie, by wydarzenie można było uznać za pogrom). Ze zjawiskiem tym wiąże się także: konflikt między dwiema grupami, stanowiący jego grunt, narastająca atmosfera pogromowa, powiązana z propagandą lub plotką ${ }^{11}$.

Jest to bardzo poręczne przybliżenie rozumienia tego terminu w kategoriach praktycznych. Nie definiuje ono co prawda pojęcia, ale właśnie przybliża termin jako stosowny do opisu czegoś więcej niż tylko zamieszek z ofiarami śmiertelnymi z jednej strony i masakrą jakiejś mniejszości z drugiej. Jako takie może być użyteczne, jednak podlega zarzutowi słusznie sformułowanemu przez Daniela Grinberga:

Dochodzimy zatem do wniosku, że wszelkie definicje odwołujące się w punkcie wyjścia wybiórczo do konkretnych przykładów [...] mijają się z celem. To samo powiedzieć można o dość częstych przypadkach definiowania przez opis. Takie pseudodefinicje, typowe dla encyklopedii, nie spełniają z zasady wymogów metodologicznych. Interpretować je należy jako symptom bezradności poznawczej. Nie wiedząc, co jest naprawdę ważne, autorzy na wszelki wypadek uzupełniają definicję o wszelkie znane sobie okoliczności wydarzeń, często nieistotne ${ }^{12}$.

Próbę naukowej dyskusji z pojęciem pogromu podjął wspomniany już Lech Nijakowski, który dokonał podstawowych rozróżnień terminologicznych oraz przeszedł do analizy samego zjawiska ,jako takiego". Odróżnił on poziomy mikro-, mezo- i makrosocjologiczne i właściwe im zjawiska, odpowiednio: linczu, pogromu i masakry, gdzie lincz jest przemocą wobec jednej lub dwóch osób, po-

10 Pogrom, [hasło w:] S. Bąk, F. Pepłowski, R. Mayenowa, Stownik polszczyzny XVI wieku, t. 26, Warszawa 1998, s. 189.

${ }^{11}$ R. Żebrowski, Pogrom, [w:] Polski słownik judaistyczny, http://www.jhi.pl/psj/pogrom (dostęp: 9.04.2020).

12 D. Grinberg, op. cit., s. 16. 
grom ma charakter lokalnej przemocy, niewychodzącej poza obręb miasta lub wsi, a masakra jest zjawiskiem makrospołecznym, pojawiającym się w warunkach wojennych. Dodatkowo autor nie uchylił się od przeciwstawienia pogromu masakrze. Ujmuje to następująco:

W odróżnieniu od masakry pogrom nie ma na celu śmierci ofiar, choć bardzo często prowadzi do zabójstw - może zatem zdarzyć się pogrom bez ofiar śmiertelnych. Jego celem jest najczęściej zbiorowe ukaranie wspólnoty ofiar za rzeczywiste lub domniemane działania. W czasie pogromów rabuje się i niszczy mienie ofiar, znieważa i niszczy symbole tożsamości grupowej, gwałci, bije i okalecza ofiary, ale rzadko celowo morduje. Jak poucza Podręczny słownik języka polskiego, pogrom to ,gromadne pobicie jednej części ludności przez drugą”, masakra zaś to „wycięcie w pień, zniszczenie” (Arct, Bondy-Łempicka 1957: 137, 227). Warto te intuicje językowe zachować. Wiele ofiar pogromów to osoby zmarłe w wyniku obrażeń. Dlatego też w porównaniu z masakrami pogromy przynoszą relatywnie niewiele ofiar śmiertelnych. Oczywiście granica między pogromem a masakrą jest płynna $^{13}$.

Nijakowski odróżnił pogrom od linczu, zaznaczając, że pogrom może się od niego zacząć. Analogicznie granica między pogromem a masakrą jest płynna. Czy więc te odróżnienia, skonstruowane jako przeciwstawienia, mają jakiś sens? Odpowiedź kryje się w zaakcentowaniu przez Nijakowskiego w tej definicji części kluczowej — chodzi o przekazanie komunikatu: „Nie jesteście tu mile widziani” oraz zbiorową formę kary wobec całej społeczności:

W przypadku pogromu idzie nie o zabicie części czy całości danej lokalnej wspólnoty, ale o jej ukaranie. Pogrom może mieć na celu albo ukaranie społeczności za domniemane zbrodnie jej członka, albo (ponownie w świadomości jej sprawców) zmuszenie ofiar do wycofania się z określonego typu aktywności lub opuszczenia danej miejscowości ${ }^{14}$.

Warto również zauważyć, że dla Nijakowskiego mobilizacja pogromowa jest żywiołowa - pogrom to thum niezorganizowany i powstający spontanicznie. To jednak jedynie w pewnym stopniu zbliża nas do zrozumienia społecznego charakteru pogromu i dynamiki wynikającej z tego, czym pogrom jest, jaka mobilizacja społeczna wywołuje pogrom i do jakich zdarzeń może on doprowadzić. Teoretyczny słownik wskazanego autora odróżnia pogrom od linczu i masakry. Nie uwzględnia jednak pewnego typu eufemizacji, która była wielokrotnie stosowana w PRL przez władze do dezinformowania i zniekształcania obrazu wydarzeń w czasach kryzysu. Na przykład podczas antysemickiej nagonki w marcu 1968 roku ataki na Żydów prowadzono pod hasłem antysyjonizmu. Podobnie nie nazywano rzeczy po imieniu w okresie rewolty robotniczej na Wybrzeżu w 1970 roku, gdzie doszło do masakry robotników. Prasa reżimowa nazywała robotników „chuliganami” i „elementem awanturniczym”, ale nie pisała o masakrze. Po 1981 roku, w odniesieniu do buntu w 1970 roku, stosowano takie wyrażenia jak: „wypadki grudniowe” lub „wydarzenia grudniowe”, „zamieszki” czy „zajścia”.

\footnotetext{
${ }^{13}$ L. Nijakowski, op. cit., s. 68.

${ }^{14}$ Ibidem, s. 69.
} 
Praktyka eufemizowania niewygodnych zdarzeń zachowała się i przetrwała przemiany ustrojowe. O eufemistycznym określaniu pogromu we Lwowie jako czynu „pijanego motłochu” w 1918 roku pisał także Grzegorz Gauden w swojej niedawno wydanej książce ${ }^{15}$, a o zjawisku eufemizacji w polskim dyskursie publicznym w kontekście pogromu lwowskiego mówił tak:

Ta semantyka się cały czas kłania „Tam nie było pogromu, były wydarzenia, były rozruchy, były jakieś napady i tak dalej”. To jest tak naprawdę ta „polska szkoła” opisywania tych wydarzeń przez wiele lat, która jest w zasadzie powtarzaniem tez Mączyńskiego, które są czystym kłamstwem $^{16}$.

Komentarz Gaudena, w którym nazywa on problem eufemizacji pogromu ironicznie „polską szkołą” opisywania wydarzeń, wydaje się odnosić nie tylko do okresu PRL, lecz także do czasów po 1989 roku.

Jeśli pogrom jest czymś spontanicznym i samonapędzającym bez odgórnej koordynacji, warto byłoby zauważyć, że trudno będzie go odróżnić od zamieszek. Zamieszki, choć są zdarzeniem często towarzyszącym pogromom, jak masakry, mogą występować zupełnie oddzielnie. Pogrom jednak może zacząć się od zamieszek, tak jak dla Nijakowskiego pogrom może zacząć się od linczu, a skończyć masakrą ${ }^{17}$. Jednak bardzo często spotyka się w dyskursie potocznym i publicystycznym opinię, że zamieszki i chuligańskie wybryki w y k lu c z a ją motywacje rasistowskie na podobnej zasadzie, jak motywacja rabunkowa rzekomo miałaby przeczyć antysemityzmowi szabrownika. Zamieszki, tak samo jak każda inna forma zbiorowej przemocy, mogą mieć charakter rasistowski i nie należy ulegać tutaj skojarzeniom i obrazom telewizyjnym, mocno utrwalającym jedynie kryminalny i chuligański charakter „zajść”, „wystąpień”, „niepokojów”. Należy tutaj dodać, że takiemu zabiegowi eufemizacyjnemu jak „kryminalizowanie” sprawców pogromu towarzyszy przedstawienie jego sprawców jako motłochu lub marginesu społecznego. W ten sposób bunty robotników w PRL władza przedstawiała jako zamieszki i ekscesy wywołane przez element chuligański i unikała konfrontacji z rzeczywistym podłożem ,zajść”.

Inna istotna cecha pogromu to ta, o której — powołując się na amerykańską badaczkę pogromów rasistowskich Robertę Senechal De La Roche - wspomniał Piotr Forecki: przywrócenie hierarchii społecznej i kontroli nad mniejszością. Pisał on w kontekście marca '68, że

Żydzi w Polsce naruszyli podobną normę. Wykroczyli poza zarezerwowane dla nich i określone kulturowo miejsce pariasa. Stali się widoczni nie tylko w partii, urzędach publicznych, admini-

15 G. Gauden, Lwów - kres iluzji. Opowieść o pogromie listopadowym, Kraków 2019, s. 122.

${ }^{16}$ Relacja ze spotkania wokół książki G. Gaudena Lwów - kres iluzji. Opowieść o pogromie listopadowym, https://www.jhi.pl/blog/2019-10-10-relacja-ze-spotkania-lwow-kres-iluzji-opowiesc-opogromie-listopadowym-1918 (dostęp: 9.04.2020).

${ }^{17}$ L. Nijakowski, op. cit., s. 68-69. 
stracji państwowej, ale przede wszystkim w innych, społecznie pożądanych, miejscach pracy.

Samowolnie opuścili getto, czym zaburzyli porządek w strukturze i hierarchii społecznej ${ }^{18}$.

Uwagi te można zastosować do sytuacji zarówno Żydów, jak i Romów, dla których miejsce wyznaczone na marginesie społecznym przekształciło się w normę kulturową i piętno - dodatkowo owiane aurą romantyzmu ${ }^{19}$.

Dla wydarzeń w Oświęcimiu znaczenie ma także definicja, czy też może rozumienie, pogromu badacza antysemityzmu Leona Poliakova ${ }^{20}$, przywołane przez Kapralskiego jako jedna z hipotez — obok hipotezy kozła ofiarnego - wyjaśniających te wydarzenia. Dla Poliakova istotny był czas kryzysu (na przykład wojna lub święto), funkcjonalność ofiar, które mogą stać się kozłem ofiarnym, element prowokacji, a także uprzedzenie i zabobon, które często prowadzą do wybuchu przemocy, bierna postawa władz oraz przerzucenie winy na ofiary. Zarówno całość koncepcji Poliakova, jak i jej kluczowa część, a więc hipoteza kozła ofiarnego, może jednak być niewystarczająca. Jak zauważa Nijakowski²1, weszła już ona do języka potocznego i — dodajmy — w wypadku doświadczenia Romów stała się nawet przysłowiowa: „Kowal zawinił — Cygana powiesili”. Jest jednak często krytykowana ${ }^{22}$. W przypadku pogromu w Oświęcimiu oraz innych tego typu wydarzeń może ona być wygodna dla badacza, lecz może także przysłaniać inne, „lokalne przyczyny” lub nie wyjaśniać, dlaczego mniejszość stała się kozłem ofiarnym na jednym terenie, a na innym, gdzie warunki kryzysowe były podobne, już nie. Rozumienie pogromu przez Poliakova ma moim zdaniem jednak tę pozytywną stronę, że akcentuje złamanie tradycyjnego porządku i nakierowuje uwagę na intencje sprawców, którzy wykazują chęć jego przywrócenia.

Stosując te definicje do zdarzeń w Mławie w 1991 roku, można łatwo zauważyć ich przydatność. Po restauracji kapitalizmu w Mławie doszło do antyromskich rozruchów, które zapisały się — w przeciwieństwie do zdarzeń z Oświęcimia w świadomości potocznej jako pogrom, a nie zamieszki. W tej sprawie wypowiedziała się para socjologów: Jan Poleszczuk i Anna Giza-Poleszczuk w raporcie wykonanym na zlecenie CBOS-u ${ }^{23}$.

Romowie w wyniku polityki władz zostają przymusowo osiedleni w Mławie w barakach w 1964 roku. Nie byli oni w żaden sposób związani z lokalną społecznością. Jak piszą autorzy raportu, ,nie odnotowano żadnych poważniejszych konfliktów"; Romowie nie wyróżniają się także statusem materialnym. Zajmują się

18 P. Forecki, op. cit., s. 52.

19 S. Kapralski, The evolution of anti-gypsyism in Poland: From ritual scapegoat to surrogate victims to racial hatespeech?, „Polish Sociological Review” 2016, nr 1, s. 103-104.

${ }^{20}$ Definicję pogromu podaję za: S. Kapralski, Refleksje..., s. 242.

${ }^{21}$ L. Nijakowski, op. cit., s. 255.

22 Zob. ibidem, s. 255-256.

23 A. Giza-Poleszczuk, J. Poleszczuk, Cyganie i Polacy w Mławie. Konflikt etniczny czy spoteczny? Raport na zlecenie CBOS, Warszawa 1992. W dalszej części artykułu przedstawiam przebieg zajść w Mławie za tym raportem. 
handlem i od czasu do czasu podejmują stałe zatrudnienie. Starają się zaprzeczyć stereotypowi nienadającego się do pracy Cygana-złodzieja i na ogół się to udaje. Co ważne, Romowie piją mniej niż Polacy i są postrzegani jako żyjący w solidarnej wspólnocie. Są katolikami, ale nie uczestniczą w życiu wspólnoty religijnej, mają swojego kapłana romskiego pochodzenia, który specjalnie przyjeżdża z okazji różnych uroczystości. Podczas świąt katolickich związanych z kultem zmarłych i świętych Romowie pojawiają się na cmentarzach. Ich żałoba jest zdecydowanie odmiennie przeżywana.

Funkcjonowanie we wspólnocie wciąż jednak opiera się na negatywnym stereotypie Cygana „biednego, brudnego i wesołego”, który przetrwał okres II wojny światowej. Eksterminacja Romów podczas wojny nie przedostała się do powszechnej świadomości i nie zakorzeniła w niej, przez co brakuje współczucia dla Romów jako ofiar hitleryzmu w społeczeństwie większościowym. Stereotyp uchował się w niezmienionej formie. Można powiedzieć, że wzajemne kontakty między tymi grupami istnieją, ale większość polska nie jest zainteresowana kontaktami poza powierzchownym potwierdzaniem niekorzystnego stereotypu, który utrwala podporządkowaną pozycję Romów i ich funkcjonowanie na marginesie.

Dodatkowo obowiązek szkolny nie jest ściśle przestrzegany $\mathrm{w}$ stosunku do dzieci romskich z powodu segregacji rasowej. Systemowa dyskryminacja funkcjonująca do dziś w instytucjach oświatowych nie jest jedynym problemem Romów. Istniejące uprzedzenia wśród starszyzny romskiej odnośnie do edukacji utrudniają egzekwowanie przez państwo obowiązku edukacyjnego i dają dogodną wymówkę do zaniechania działań i segregacji. Podobnie wygląda sprawa z obowiązkiem wojskowym - Romowie nie są chętnie przyjmowani na służbę, chociaż teoretycznie podlegają temu samemu obowiązkowi wojskowemu. Rom w jednostce przeszkadza, ponieważ jest potencjalnym obiektem żartów, drwin i odrzucenia przez kolegów. Rzadko dochodzi do małżeństw mieszanych z uwagi na niską pozycję społeczną Romów oraz inne zasady wchodzenia w związki małżeńskie. Romskie kobiety wychodzą za mąż w młodszym wieku, w związku z czym mężczyźni szukają znacznie młodszych od siebie kobiet. To wszystko pogłębia tylko izolację, która z kolei jest korzytnym stanem rzeczy do utrzymywania negatywnego i powierzchownego stereotypu. Romowie postrzegani są jako lubiący się bawić, „,bumelanci”, dla których nie liczy się praca, ale funkcjonowanie we własnej, starannie odgrodzonej, społeczności. Stosuje się wobec nich znaną zasadę odpowiedzialności zbiorowej, co wynika z tego, że Polacy nie odróżniają jednego Roma od drugiego.

W latach osiemdziesiątych dochodzi do gwałtownych zmian związanych z bogaceniem się niektórych rodzin romskich, prawdopodobnie zarabiających coraz więcej na handlu. Prowadzi to do zachwiania tradycyjnej hierarchii, w której Cygan to wciąż ktoś „biedny, brudny i wesoły”. Bogatsi Romowie zaczynają wraz $\mathrm{z}$ awansem materialnym odczuwać okazję do poprawienia swojego wizerunku w oczach większości polskiej. Stawiają nowe domy, zwane w Mławie belwederami, które szybko stają się obiektem zazdrości. Bogactwo Romów prędko staje się 
przysłowiowe, a oni sami, według autorów raportu, podsycają ten nowy stereotyp, sugerując w rozmowach z Polakami, że mają kontakty wśród władz, przez co chcą być uznawani za ważnych i poważanych obywateli. Władza wójta ulega erozji, młodzi Romowie nie widzą już w tradycyjnej starszyźnie aż tak wielkiego autorytetu, ponieważ można sobie go zaskarbić awansem materialnym. Pojawiają się nowe szybkie samochody, których kierowcami są młodzi Romowie. Pojawia się także ostentacyjna konsumpcja, charakterystyczna w momencie awansu dla grupy wcześniej defaworyzowanej.

$\mathrm{Na}$ to wszystko nakłada się kryzys społeczny związany z ogromnym wzrostem bezrobocia w Mławie i restauracją kapitalizmu. Bezrobocie osiąga tam rekordowy poziom $35 \%$ przy ogólnym poziomie $10 \%$ w skali kraju, co pokazuje, jak ogromna musiała być frustracja wywołana zmianami ekonomicznymi i spadkiem poziomu życia większości mieszkańców. Szczególnie zła sytuacja dotyka młodych, zwłaszcza gdy chodzi o dostępność mieszkań. Wkraczają nowe, wcześniej nieobecne, formy więzi społecznej. Polacy postrzegają Romów jako zachowujących się nieodpowiednio, z wyższością patrzących na innych mieszkańców. Kobiety romskie spotykają się z odrzuceniem i stygmatyzacją, kiedy kupują większą ilość wędlin w sklepach. W skrócie mówiąc, Romowie przestają się zachowywać zgodnie z warunkami akceptacji zapisanymi w stereotypie. Nie czują się podporządkowani i gorsi niż Polacy. Ci ostatni twierdzą, że Romowie zachowują się arogancko, utrzymują, że mają rządzących w kieszeni i są „ustawieni”. Autorzy opracowania częściowo potwierdzają prawdziwość takich przechwałek.

Nie tylko więc stereotyp jest przełamany, lecz także aspiracje Romów są o wiele większe. Chcą oni stać się częścią warstwy rządzącej. Ich bogactwo zaczyna być postrzegane samo w sobie jako podejrzane, zdobyte w nieuczciwy sposób, ponieważ bogactwo jako takie zaczyna być kojarzone z oszustwami i malwersacjami. Wpływają na to lokalne afery, stereotyp bogacza aferzysty wpływa niekorzystnie na percepcję romskiego awansu. W tych warunkach trzeba tylko iskry, żeby doszło do zbiorowej przemocy.

Dochodzi do wypadku samochodowego spowodowanego przez młodego Roma. Ginie dwudziestojednolatek, młody żołnierz na przepustce, poszkodowana jest jego dziewczyna, zaledwie siedemnastoletnia. Młody romski sprawca ucieka z miejsca wypadku. Dwa dni później wójt romski z Mławy doprowadza sprawcę na komendę, kolejnego dnia sprowadzony zostaje samochód. Nie uspokaja nastrojów nawet rozwieszenie przez komendanta w całym mieście plakatów informujących o tym, że sprawca został zatrzymany. Prawdopodobnie tożsamość ofiary, młodego żołnierza, wpływa na percepcję samego zdarzenia. Romowie są bowiem oskarżani o posiadanie przywilejów i kontaktów, które mają rzekomo zwalniać ich od służby wojskowej ${ }^{24}$.

${ }^{24}$ Romowie w PRL nie byli formalnie zwolnieni ze służby wojskowej, ale ich obecność w wojsku była postrzegana jako uciążliwa. Anna Giza-Poleszczuk i Jan Poleszczuk sugerują, że władze 
Wnioski autorów raportu co do charakteru przemocy antyromskiej i jej pogromowości są jednak negatywne. Stwierdzili oni, że w Mławie nie mogło dojść do pogromu, dlatego że za sytuację społeczną odpowiedzialne były czynniki zewnętrzne (bezrobocie, bieda młodzieży), ale też częściowo sami Romowie, którzy przechwalali się swoim awansem w ramach lokalnej społeczności. Jeśli uznać przemoc antyromską za pogrom - stwierdzili — trzeba byłoby zignorować ekonomiczne źródło tych wystąpień. Ich zdaniem ekonomiczny charakter przemocy jest oczywisty, a etniczny - wątpliwy. Oba te aspekty nie mogą się na siebie nakładać. Tymczasem nigdy w historii przemocy wobec mniejszości nie było tak, by sytuacja społeczno-ekonomiczna mniejszości, a także warunki socjalne, w jakich znajduje się większość, były wyraźnie odgrodzone od kwestii etnicznych. Sami autorzy potwierdzili to poniekąd, przywołując (słusznie) koncepcję stereotypu autorstwa Stanisława Ossowskiego, w której znajdują się wyobrażenia większości wobec cech mniejszości związanych z jej usytuowaniem ekonomiczno-społecznym. A więc stereotypizacja, która często prowadzi do ksenofobii i konfliktów etnicznych, ma podłoże społeczne i ekonomiczne i nie może być oddzielona od relacji i stosunków między mniejszością a większością. Tak więc, w mojej ocenie, analiza teoretyczna stawiała sprawę klarownie i poprawnie, natomiast wnioski wyciągnięte przez autorów okazały się błędne czy też wątpliwe. Można więc przejąć założenia teoretyczne autorów, nie przejmując rezultatów ich wnioskowań dotyczących samego pogromu.

Wszystko to prowadzi do pytania o to, czy zjawiska pogromu można wyjaśnić, sięgając jedynie do pojęcia stereotypu, którego złamanie powoduje mobilizację większości wobec mniejszości. Autorzy raportu stwierdzili bowiem, że sytuacja w Mławie była po części wywołana awansem społecznym Romów i degradacją społeczną Polaków. To właśnie ta sytuacja była pośrednią przyczyną przemocy antyromskiej, albowiem agresja wyładowała się tam, gdzie stereotyp się załamał, gdzie przekonanie o nieakceptowalnym odwróceniu porządku i norm było najsilniejsze. Jednocześnie jednak postrzeganie jedynego źródła przemocy pogromowej w stereotypie i jego przełamaniu nie wyjaśnia, dlaczego przemoc antyromska pojawia się w okresach kryzysów społeczno-gospodarczych. Znany problem odsuwania odpowiedzialności i używanie argumentu o kryzysie gospodarczym jako pretekstu do usprawiedliwienia sprawców prowadzi zarazem do dystansowania się od jednostronnego przyznawania pierwszeństwa czynnikowi „zewnętrznemu". Czynnik ten jest nieodłączny od kwestii ksenofobii, jak w omówionym przykładzie Mławy, i nie należy oddzielać przyczyn ekonomicznych od „społeczno-kulturowych" źródeł niechęci wyrosłej na stereotypach i uprzedzeniach opartych na utrwalonych wyobrażeniach kulturowych.

chętnie zgadzały się na odroczenie służby lub akceptowały w tym względzie uniki stosowane przez Romów, na przykład w postaci łapówek. 
Każdy z tych elementów, a więc: przemoc poprzedzona plotką lub propagandą, przekazanie komunikatu: „Nie jesteście tu mile widziani” i niszczenie mienia jako cel, lokalność zjawiska i źródeł konfliktu oraz kryzys ekonomiczny występujący w ścisłym związku ze społecznym statusem i prawami mniejszości wyraźnie naznaczonej piętnem niższości oraz jej nagłym awansem w warunkach zmiany systemowej lub głębokich i burzliwych zmian społecznych, wydaje się użyteczny w eksplikacji wydarzeń w Oświęcimiu w 1981 roku. Analiza ówczesnej przemocy w Oświęcimiu wskazuje, że oba elementy - ekonomiczny i społeczno-kulturowy — zadziałały we wzajemnym sprzężeniu i doprowadziły do wybuchu pogromu. Społeczeństwo PRL-u dotknięte trwałymi kryzysami niedoboru dóbr sprzyja temu, aby w jego obrębie, czyli w „społeczeństwie kolejek”, hierarchicznym systemie organizacji życia osobistego i zbiorowego, opartym na nieformalnych układach i amoralnym familiaryzmie, wprowadzić oddolną „kontrolę”, zawistną i niechętną każdemu, komu się „udało”. Dodatkowo państwo zbudowane na czystkach etnicznych samo swoją polityką podsyca istniejące napięcia i generuje nastroje ksenofobiczne, utrwalając istniejące i stwarzając kolejne. W takich warunkach Romowie jako grupa defaworyzowana, stygmatyzowana, pojawiająca się w wyniku mikroskopijnego awansu jako „partner”, na przykład w kolejce po mięso i w kolejce po piwo, wywołuje negatywne reakcje ${ }^{25}$.

W Oświęcimiu Romowie pracowali (?) w przemyśle chemicznym, w rzemiośle jako kotlarze oraz bogacili się na handlu luksusowymi dobrami, które przywozili z ówczesnej Jugosławii, Włoch i NRD. Handlowali także złotem i pracowali przy odzyskiwaniu metali szlachetnych z odpadów przemysłowych. Ma to ogromne znaczenie w latach siedemdziesiątych, kiedy sytuacja gospodarcza staje się trudna, szczególnie w drugiej połowie dekady. Wygląda więc na to, że romskie metody zdobywania środków do życia w większej części mogą być postrzegane jako niemoralne lub mogły być w ogóle niewidoczne.

Rozruchy pogromowe w Oświęcimiu zaczynają się od złamania ważnej normy społecznej w dobie kryzysu gospodarczego i społecznego - nieprzestrzegania kolejki, co stanowiło wówczas nieuniknione zarzewie konfliktu.

W Oświęcimskiej gospodzie doszło do przepychanki i konfliktu między Romem Janem Gomanem a jednym z Polaków. Poszło o miejsce w kolejce, wywiązała się bójka, która w konsekwencji doprowadziła do ucieczki Jana Gomana i mobilizacji polskiego tłumu przeciwko Romowi. Tłum ten ruszył za Gomanem pod jego dom i zaczął wzrastać liczebnie. Ostatecznie milicja przybyła do jego domu i eskortowała go do aresztu.

W tym czasie thum rozpoczął zamieszki nie tylko pod domem Roma, ale w całym Oświęcimiu. Około 200 osób, głównie pijanych, rozeszło się po całym mieście i zaczęło niszczyć samochody romskie, atakować ich domy butelkami

${ }^{25} \mathrm{O}$ ważnym w kontekście zbiorowej przemocy aspekcie norm kolejkowych pisał S. Kapralski, Refleksje..., s. 238-239. 
i kamieniami. W tym czasie w mieście mieszkało około 70-80 rodzin romskich. Wiadomo o pięciu punktach zapalnych zamieszek. Milicja zaprowadziła spokój, pacyfikując agresywny thum. Następnego dnia dwa razy liczniejsza grupa (około 400 osób $^{26}$ ), także podpitych, ruszyła pod budynek partii. Domagano się ,zrobienia porządku z Cyganami z Oświęcimia" i grożono, że jeśli władza nie podejmie żadnych działań, mieszkańcy sami się problemu pozbędą. Władze zaprosiły do rozmów przedstawicieli tłumu oraz wójta romskiego Władysława Kwiatkowskiego. Uformował się Komitet do Spraw Wypędzenia Cyganów z Miasta. Przedstawiciele Romów eskortowani przez milicję zostali doprowadzeni do budynku władz miejskich. W towarzystwie lokalnego prokuratora zaproponowano Cyganom wysiedlenie do obozu pracy pod Bielskiem. Cyganie ustami wójta kategorycznie nie zgodzili się na takie warunki, ale wystarczyło, aby podjęli decyzję o wyprowadzce ich z Oświęcimia do innych miast. Romowie zaakceptowali także propozycję wyjazdu z Polski. Władze wydały Romom paszporty w jedną stronę, czyli tak zwane dokumenty podróży. Większość Romów z Oświęcimia odpłynęła 13 grudnia, w dniu wprowadzenia stanu wojennego, do Szwecji. Kiedy dobili do brzegu w porcie miasta Lund, czekali na nich dziennikarze złaknieni informacji o stanie wojennym w Polsce. Prom pełen Romów stanowił niemałe zaskoczenie. Romowie otrzymali azyl i zostali przyjęci.

Wersje romska i polska różnią się jednak znacząco co do przebiegu wydarzeń. Roman Kwiatkowski, syn wójta romskiego z Oświęcimia, podkreśla, że Jan Goman nie sprowokował bójki w gospodzie, ale się bronił. $Z$ relacji zaś byłego milicjanta z Oświęcimia ${ }^{27}$ wynika, że było na odwrót. Również w sprawie rozległości zamieszek wersje różnią się, choć nieznacznie.

„Zajścia” w Oświęcimiu, jak wiemy, poprzedziły plotki i pogłoski ${ }^{28}$, między innymi o tym, że Romowie otrzymają mieszkania. Z uwagi na ówczesną sytuację społeczno-ekonomiczną pogłoska ta faktycznie mogła rozjątrzać nienawiść do Romów, których postrzegano jako zbyt uprzywilejowanych.

Roman Kwiatkowski jako prowodyra i lidera tłumu wskazuje Władysława Janika, brata szefa SB z Oświęcimia. Pojawia się hipoteza o prowokacji ze strony służb, choć z uczciwym zastrzeżeniem, że jest to hipoteza niepewna i raczej pomocnicza. Nie wyjaśniałaby ona całego zajścia, nawet jeśli okazałaby się prawdą.

Wedle byłego milicjanta liderem thumu był Marian Składnik i to on pertraktował z zastępcą komendanta. Nie doszło też do siłowego rozproszenia tłumu pałkami ZOMO. Zgodnie z relacją mojego informatora ZOMO wówczas w ogóle nie stacjonowało w Oświęcimiu, a zastępca komendanta uspokoił nastroje, dochodząc ze Składnikiem do porozumienia.

${ }^{26}$ IPN, Informacje Dzienne MSW z dn. 21 i 22 października, IPN BU 0717/6/7, IPN BU $1585 / 15913$.

27 Wywiad autora artykułu z byłym milicjantem z Oświęcimia przeprowadzony w grudniu 2019 roku.

${ }^{28}$ R. Kwiatkowski, op. cit. 
Roman Kwiatkowski mówi o pogromie, natomiast były milicjant kategorycznie określa zdarzenie jako antycygańskie zamieszki, podkreślając, że do pogromu nie doszło. Nie jest to tylko spór werbalny, kwestia tego, co jest pogromem, a co nie, ma oczywiście olbrzymie znaczenie dla kształtowania się świadomości wagi problemu oraz sposobu mówienia o nim, a także dla pamięci kształtującej tożsamość romską ${ }^{29}$.

Status przemocy antyromskiej w Oświęcimiu można określić jako przemoc pogromową. Nawiązując do definicji Nijakowskiego, należy podkreślić, że celem pogromu nie jest mord ani zabójstwo, ale przekazanie komunikatu: „Nie chcemy was tutaj" i zbiorowa kara. Dodatkowo wyraźnie występuje tutaj motyw przywracania hierarchii i kontroli nad mniejszością, która wyszła poza narzucone jej miejsce w strukturze społecznej. Zarzuty wobec Romów o to, że nie okazywali szacunku Polakom, towarzyszą motywacjom sprawców zarówno w Mławie, jak i w Oświęcimiu.

Kiedy doszło do uspokojenia i pacyfikacji nastrojów dzięki Milicji Obywatelskiej, następnego dnia tłum pogromowy przekształcił się w Komitet na Rzecz Wypędzenia Cyganów z Miasta. Komitet domagał się wypędzenia Romów do obozu pracy pod Bielskiem. Romowie oczywiście nie przystali na te warunki i ustalono, że mają opuścić Oświęcim. Po jakimś czasie zarządzenie o opuszczeniu miasta uległo rozszerzeniu i Romom rozdawano wspomniane „dokumenty podróży”.

Dwa dni po wydarzeniach z 21 października Roman Kwiatkowski i jego partnerka Agata Talewicz odwiedzili restaurację w Oświęcimiu. Przy wejściu widniał napis „Cyganom i psom wstęp wzbroniony”. Z okolicznych stolików powitały ich nienawistne spojrzenia. Agata, dzisiaj żona Romana Kwiatkowskiego, wspomina (wypowiedź ta jest zarejestrowana w filmie dokumentalnym Ostatni Cygan w Oświęcimiu ${ }^{30}$ ) o komentarzach, jakie słyszała, w tym najbardziej brutalnych oraz groźbach obcięcia i golenia włosów.

Warto $\mathrm{w}$ tym momencie wspomnieć, że jednym z pośrednich źródeł na temat wydarzeń w Oświęcimiu jest wspomniany film z 1992 roku Ostatni Cygan w Oświęcimiu Dżamili Ankiewicz i Marii Zmarz-Koczanowicz. Występują tam mieszkańcy Oświęcimia, którzy wprost odwołują się emocjonalnie do zaostrzonej sytuacji i wyrażają usprawiedliwienia dla przemocy pogromowej. Ponieważ film powstał jedynie dziesięć lat po wydarzeniach, pamięć o nich była świeża, a emocje nie zdążyły opaść. Rasistowskie uwagi zarejestrowane w filmie pod adresem Romów stają się dzisiaj śladem, dzięki któremu możemy spojrzeć na wcześniejsze wydarzenia jak przez soczewkę.

${ }^{29} \mathrm{O}$ aspektach związanych z pamięcią szerzej pisze S. Kapralski w cytowanym wielokrotnie artykule: idem, Refleksje...

${ }^{30}$ Ostatni Cygan w Oświęcimiu [film], reż. M. Zmarz-Koczanowicz, Dż. Ankiewicz, scen. Dż. Ankiewicz, Polska 1992. 
Wydaje się, że mechanizm przemocy staje się już zrozumiały. Przypomina sytuację z Mławy. Dwustuosobowy tłum ${ }^{31}$ urządza lincz, który po interwencji milicji przeradza się $\mathrm{w}$ trwające $\mathrm{w}$ całym mieście rozruchy pogromowe ${ }^{32}$. Rozruchy te zostają zablokowane przez policję i następnego dnia już 400 osób $^{33}$ domaga się wypędzenia Romów z miasta. Zostają więc spełnione wszystkie kryteria pogromu - wystąpienie plotek, propagandy, konfliktu jako podłoża rozwoju dynamiki pogromowej oraz cel „zamieszek” staje się jasny, kiedy dochodzi do spotkania z władzami. Jest nim wypędzenie Cyganów z miasta i przywrócenie „łamanych norm". Do więzienia w wyniku rozruchów pogromowych nie idzie żaden z uczestników „zamieszek” prócz Jana Gomana. Romowie emigrują z Oświęcimia w dniu wprowadzenia stanu wojennego; 13 grudnia 1981 roku do portu w Lund przybija prom pełen Romów. Niewielu z nich zdecyduje się powrócić po 1989 roku do swojego macierzystego miasta.

Istniejące rozwiązanie problemu terminologicznego w odniesieniu do Oświęcimia, zaproponowane przez Sławomira Kapralskiego, wydaje się problematyczne, choć w świetle zebranych przeze mnie informacji nie da się odrzucić hipotezy kozła ofiarnego. Słabości koncepcji Poliakova w odniesieniu do pogromów antyromskich wskazywałem już wcześniej. Pewne elementy tej koncepcji można jednak dostrzec $\mathrm{w}$ przebiegu wypadków, szczególnie zaś element zabobonów i uprzedzeń (plotki pogromowe), dodatkowo przerzucenie winy na Romów łączy się z elementem prowokacji (to Jan Goman miał sprowokować bójkę w barze). Nie wydaje mi się jednak, żeby te elementy były decydujące i mogły przesądzić o określeniu zdarzeń w Oświęcimiu jako pogromu. Wydarzenia te wyraźnie wpi-

${ }^{31} \mathrm{~W}$ notatce o wydarzeniach z 21 października w Oświęcimiu w informacjach dziennych MSW czytamy: „Uczestnicy zbiegowiska zaczęli obrzucać mieszkanie Gomana kamieniami i butelkami. Zażądali oni zatrzymania go przez funkcjonariuszy MO. Funkcjonariusze MO zatrzymali J. Gomana i pod ochroną kordonu milicji wywieźli go z miejsca zagrożenia do aresztu KW MO w Bielsku Białej. Uczestnicy zgromadzenia w kilku grupach udali się następnie w kierunku miasta, uszkadzając po drodze następnie dwa samochody stanowiące własność Cyganów. W wyniku dalszych działań MO doprowadzono do przywrócenia ładu i porządku w mieście" — IPN BU 0717/6/7.

32 „Rozruchy pogromowe” wydają się lepszym połączeniem leksykalnym niż „zamieszki pogromowe", ale w zasadzie oznaczają zbiorową, żywiołową przemoc na tle rasowym, wymierzoną w mniejszość na danym terenie. Określenie „zamieszki”, co opisywałem wcześniej, może być niezrozumiałe w kontekście pogromu ze względu na częste skojarzenie z bójkami stadionowymi lub chuligańskimi wybrykami, lecz w ścisłym sensie teoretycznym mogą mieć charakter rasistowski, towarzyszyć pogromom lub się w nie przeradzać.

$33 \mathrm{~W}$ notatce o wydarzeniach z 22 października w Oświęcimiu w informacjach dziennych MSW czytamy: „Dnia 22 bm. w Oświęcimiu /woj. bielskie/ o godzinie 17 przed budynkiem KM PZPR zgromadziło się ok. 400 osób, przeważnie pod wpływem alkoholu, które zażądały wysiedlenia Cyganów z rejonu Oświęcimia. Po rozmowach przeprowadzonych przez prokuratora rejonowego, sekretarza KM PZPR i prezydenta miasta z delegacją wyłonioną z tłumu, o godzinie 21.00 tłum rozszedł się. Władze miasta podjęły decyzję o wstrzymaniu sprzedaży alkoholu w dniu $23 \mathrm{bm}$. Zarządzono również spotkanie z przedstawicielami rodzin cygańskich celem przypomnienia dyscypliny meldunkowej i zasad współżycia społecznego" — IPN BU 1585/15913. 
sują się w definicję Nijakowskiego - doszło do niszczenia mienia i ataku na całą mniejszość w celu wypędzenia jej z Oświęcimia, na co wskazywał postulat komitetu pogromowego zawiązanego dzień później. Towarzyszące pogromowi zamieszki i inicjujący je lincz na Janie Gomanie odzwierciedlają płynność kategorii pogromu, o której pisał Nijakowski. Kluczowe w tym kontekście wydaje się podobieństwo, jeśli chodzi o genezę pogromu, do doświadczeń żydowskich opisanych przez Piotra Foreckiego - Romowie zostali wypędzeni z Oświęcimia z tego powodu, że „wyszli z getta” i przestali zachowywać się jak pariasi. Przemoc pogromowa była narzędziem do osiągnięcia celu, jakim było przywrócenie zachwianego z powodu kryzysu porządku hierarchicznego.

$\mathrm{Na}$ koniec chciałbym podkreślić, że istnieją powody do zachowania sceptycyzmu wobec szerokiego stosowania pojęcia pogromu. Uwzględniając to, co wcześniej napisałem o zamieszkach, mianowicie że mogą one towarzyszyć pogromom, trzeba pamiętać, iż same nie stanowią one wystarczającego kryterium do nazwania przemocy pogromową. Jeśli bowiem nie odróżnimy rozruchów pogromowych od zwykłych zamieszek, które wybuchły na przykład w wyniku tlącego się konfliktu sąsiedzkiego, może się okazać, że każdy konflikt z użyciem przemocy zostanie uznany awansem za pogrom. Doprowadzi to do dewaluacji tego pojęcia i dalszego jego rozmycia. Zanim stwierdzimy pogrom, musimy więc uważnie przyjrzeć się wszystkim okolicznościom oraz określić, czy faktycznie skala zajść pozwala o nim mówić. Przywoływany przeze mnie Nijakowski, powołując się na Georga Simmla ${ }^{34}$, podkreśla rolę czynnika ilościowego i agregacji przemocy. Może to być z pewnością jeden z wielu pomocniczych czynników odróżniających pogrom, który wybucha $\mathrm{w}$ celu przepędzenia mniejszości z danego terenu, od zamieszek, które ustają w momencie opadnięcia emocji wywołanych izolowanym wydarzeniem lub konfliktem.

\section{The notion of "pogrom" and anti-Roma violence in Poland}

Abstract

The article describes the results of the author's research about the notion of "pogrom" as well as results of his inquiries on anti-Roma violence in Oświęcim in 1981. The author focuses on critique of dominating hypotheses and theories that deal with the events in Oświęcim and describes those events as pogrom in character. The main thesis of the article is theoretically based on the report by Anna Giza-Poleszczuk and Jan Poleszczuk on the Mława violence in 1991 and their theoretical

34 „Aspekt ilościowy ma znaczenie dwojakie: negatywne, polegające na tym, że pewne formy rozwoju, konieczne czy też możliwe w danych warunkach wewnętrznych lub innych, mogą się urzeczywistnić wyłącznie poniżej bądź powyżej pewnej granicy liczebności” — G. Simmel, Socjologia, przeł. M. Łukasiewicz, Warszawa 1975, s. 111, cyt. za: L. Nijakowski, op. cit., s. 62. 
framework which they derived from the works of Polish sociologist Stanisław Ossowski, and his theory of the stereotype in particular. The second crucial point of the author's argument is a reference to the article by Piotr Forecki, who revived the category of pogrom to the studies of the anti-Semitic campaign in March 1968 in Poland, as well as the definition of a pogrom by Lech Nijakowski.

Keywords: "pogrom”, Roma, Oświęcim, discrimination, collective violence, nationalism

\section{Bibliografia}

Forecki P., Marzec '68 jako pogrom. Brakująca kategoria opisu, [w:] Tożsamość po pogromie. Zapisy literackie pokolenia marca '68, red. P. Czapliński, A. Molisak, Warszawa 2019.

Gauden G., Lwów — kres iluzji. Opowieść o pogromie listopadowym, Kraków 2019.

Giza-Poleszczuk A., Poleszczuk J., Cyganie i Polacy w Mławie. Konflikt etniczny czy społeczny? Raport na zlecenie CBOS, Warszawa 1992.

Grinberg D., Wokót idei pogromów. Definicje, główne szkoły interpretacji, źródta nieporozumień, [w:] Pogromy Żydów na ziemiach polskich w XIX i XX wieku, t. 3. Historiografia, polityka, recepcja społeczna (do 1939 roku), red. K. Kijek, A. Markowski, K. Zieliński, Warszawa 2019.

IPN, Informacje Dzienne MSW z dn. 21 i 22 października, IPN BU 0717/6/7, IPN BU 1585/15913.

Kapralski S., The evolution of anti-gypsyism in Poland: From ritual scapegoat to surrogate victims to racial hatespeech?, „Polish Sociological Review” 2016, nr 1.

Kapralski S., Refleksje o pogromach. Na marginesie wydarzeń w Oświęcimiu w 1981 r., „Studia Romologica" 2009, nr 2.

Kwiatkowski R., Przystanek Oświęcim (rozm. przepr. Karolina Feć), http://nowaorgiamysli.pl/index. php/2017/06/10/roman-kwiatkowski-przystanek-oswiecim-romska-historia/ (dostęp: 8.04.2020).

Nijakowski L., Rozkosz zemsty. Socjologia historyczna mobilizacji ludobójczej, Warszawa 2013.

Ostatni Cygan w Oświęcimiu [film], reż. M. Zmarz-Koczanowicz, Dż. Ankiewicz, scen. Dż. Ankiewicz, Polska 1992.

Pogrom, [hasło w:] S. Bąk, F. Pepłowski, R. Mayenowa, Stownik polszczyzny XVI wieku, t. 26, Warszawa 1998.

Relacja ze spotkania wokół książki G. Gaudena Lwów — kres iluzji. Opowieść o pogromie listopadowym, https://www.jhi.pl/blog/2019-10-10-relacja-ze-spotkania-lwow-kres-iluzji-opowiesc-o-pogromie-listopadowym-1918 (dostęp: 9.04.2020).

Simmel G., Socjologia, przeł. M. Łukasiewicz, Warszawa 1975.

Żebrowski R., Pogrom, [hasło w:] Polski słownik judaistyczny, http://www.jhi.pl/psj/pogrom (dostęp: 9.04.2020).

Artur Maroń - doktorant w Instytucie Kulturoznawstwa Uniwersytetu Wrocławskiego. Prowadzi badania nad pogromami Romów w PRL. Zajmuje się nacjonalizmem jako zjawiskiem kulturowym. Interesuje go kultura jako obszar dyskryminacji, dominacji i ucisku oraz studia nad ludobójstwem, marksizm i zagadnienie kultur pracy.

304321@uwr.edu.pl 